served on the manpower panel, and a member of the AADPRT Executive Committee, Eugene Feigelson, M.D., served on the services panel of the commission.

Returns from the first annual questionnaire have resulted in the creation of an automated data bank at the Rockland Research Institute.

Mailing address: Institute of Living 200 Retreat Avenue Hartford, Connecticut 06106

\title{
AMERICAN COLLEGE OF PSYCHIATRISTS
}

A special Ad Hoc Committee has been formed, which includes Drs. Paul Fink and Shervert Frazier, to develop an examination that would be available to third-year residents. Plans are being developed to have two regional meetings in 1978 in addition to the annual meeting which will be held in New Orleans, February 8-12, 1978 at the Royal Sonesta Hotel. The officers of the college are: president: Edward
O. Harper; president-elect: Gene L. Usdin; first vice-president: Warren G. Williams; second vice-president: Shervert H. Frazier; secretarygeneral: John C. Nemiah; and treasurer: Charles E. Smith.

Mailing address: John C. Nemiah, M.D., 330 Brookline Avenue, Boston, Massachusetts 02215.

\section{ASSOCIATION OF DIRECTORS OF MEDICAL STUDENT EDUCATION IN PSYCHIATRY}

The purpose of the association is to advance and improve medical student education in psychiatry, share information, and develop standards so as to foster higher standards of education in psychiatry in medical schools. The association aims also at developing in the psychiatric educator an awareness of national trends in education as well as influencing such trends. Membership in the association is limited to the Directors of Medical Student Education in Psychiatry.

The association will have its fourth annual meeting on Friday, January 20, and Saturday, January
21, 1978 in New Orleans. The theme of the meeting and details of the agenda will be announced in a circular letter to be sent out to all of the directors.

Officers are: president: Frederick R. Hine, M.D.; vice president: Gerald A. Melchoide, M.D.: secretary: Marshall Swartzburg, M.D.; treasurer: Warner Johnson, M.D.

Mailing address: Ali A. Kawi, M.D., Liaison Editor, State University of New York, Downstate Medical Center, 450 Clarkson Avenue, Brooklyn, New York, 11203. 